\title{
Environmental impact assessment of uranium ore mining and radioactive waste around a storage centre from Mexico
}

\author{
M.I. Gaso ${ }^{1}$, N. Segovia ${ }^{2}$ and O. Morton ${ }^{2}$ \\ ${ }^{1}$ Radioactivity Surveillance Laboratory, Nuclear Research National Institute (ININ), AP. Post. \\ 18-1027, 11801 Mexico D.F., Mexico, e-mail: migp@nuclear.inin.mx \\ ${ }^{2}$ IGFUNAM, Ciudad Universitaria, 04510 Mexico, D.F., Mexico
}

\begin{abstract}
Uranium ore tailings and radioactive waste have been stored during four decades at the Mexican Storage Centre for Radioactive Waste (SCRW). An estimation of effective doses from sources of natural and artificial origin in the general population and workers is presented. The sampling points are located at the SCRW at a $200 \mathrm{~m}$ neighbouring zone of the site and at distant communities around SCRW (regional background). The effective gamma dose rates were estimated from measurements of radionuclide concentration in soil samples from 1991 to 2002. Doses from the outdoor and indoor inhalation of radon were also determined. Transfer factors for ${ }^{226} \mathrm{Ra},{ }^{210} \mathrm{~Pb},{ }^{137} \mathrm{Cs}$ and ${ }^{40} \mathrm{~K}$ from soil to wild edible species have been used to estimate the contribution of wild local foods to the dietary intake and to assess the supplementary doses received due to internal irradiation. The effective dose via the different exposure pathways estimated in the population that would live at the future in the immediate SCRW vicinity was two times higher than for the regional background.
\end{abstract}

\section{INTRODUCTION}

Ore extraction and processing may lead to technologically enhanced naturally occurring radionuclide materials (TENORM), in nuclear installations and the environment. Continuous releases of these materials to the environment may result in a buildup in the air, water and soil of some radionuclides, particularly ${ }^{226} \mathrm{Ra}$. Natural world average concentrations of ${ }^{40} \mathrm{~K},{ }^{226} \mathrm{Ra},{ }^{232} \mathrm{Th}$, and ${ }^{238} \mathrm{U}$ in the soil are $400,40,25$ and $25 \mathrm{~Bq} \mathrm{~kg}^{-1}$ respectively [1]. International radioprotection norms [2] admit for an individual from the population, an additional dose "caused" by all the natural sources via all the pathways from the region in which he lives of $1 \mathrm{mSv} \mathrm{y}^{-1}$, which has to be added to the effective dose due to the natural background of the investigated area.

At the Mexican Storage Centre for Radioactive Waste (SCRW), solid and liquid radioactive waste have been stored during four decades and uranium ore tailing piles also stood for some time before being buried in trench and specific containers. A local contamination in the soil with ${ }^{137} \mathrm{Cs}$ also occurred at the site as a consequence of a broken industrial source [3]. An environmental monitoring program has been systematically conducted at the SCRW and surrounding communities and intervention and decontamination actions, with removal of the upper soil layer and confining it into containers, were performed at the site from 1993 to 2000 [4]. Determinations of trace stable and radioactive elements have been also performed in the soil as well as some bioindicators [5], [6], [7].

In the present paper the effective gamma dose rates in air from terrestrial radionuclides, doses from the outdoor and indoor inhalation of radon and doses from ingestion of possibly contaminated local foods, were estimated to determine the radiological impact in agricultural soils of uranium mining past activities and SCRW operation. The sampling period considered is from 1990 to 2002. Workers are employed in waste and soil removing and they may be exposed to external radiation and outdoors radon inhalation only because there are no offices at the site. The enhancement of radioactivity levels was calculated in order to assess the additional doses received by the general public and workers due to external exposure and internal irradiation. 


\section{MATERIALS AND METHODS}

The SCRW site ( $\left.19^{\circ} 47^{\prime} 40^{\prime \prime} \mathrm{N} ; 98^{\circ} 50^{\prime} 10^{\prime \prime} \mathrm{W}\right)$ is located in the State of Mexico, Mexico at altitudes between 2470 and $2490 \mathrm{~m}$, in the middle part of the Mexican Neovolcanic belt (Figure 1). The climate is temperate, sub-humid with an average yearly temperature of $14{ }^{\circ} \mathrm{C}$, ranging from 6 to $32{ }^{\circ} \mathrm{C}$. During the rainy season from June to October, the mean annual precipitation is $638.5 \mathrm{~mm}$. The sampling points from SCRW are: Zone I, corresponding to the area where the ore was piled and the ${ }^{137} \mathrm{Cs}$ contamination occurred; Zone II at a lower altitude than Zone I was a private property until 1993; Zone III at the bottom of the slope, the place where rain water was accumulated previously to leave the SCRW and Zone IV that include all the other sampling points inside the SCRW. Five sampling points are also located in a $200 \mathrm{~m}$ neighbouring zone of the site (Zone V). That external land is a private property used for local agricultural practices. Four distant communities in a $10 \mathrm{~km}$ radius around the site correspond to the regional background (Zone VI).

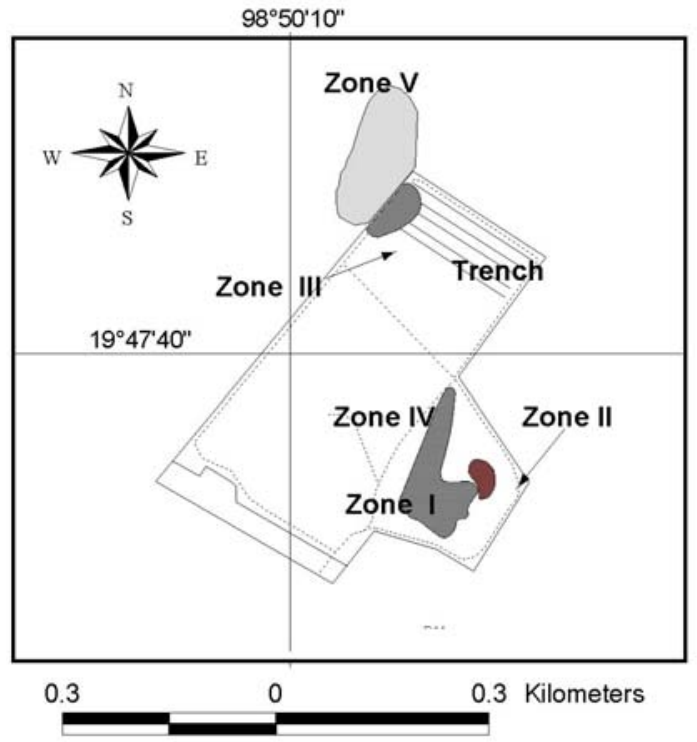

\subsection{Gamma-ray spectrometry and dose evaluation from the soil activity}

Several data series samples of ${ }^{235} \mathrm{U},{ }^{226} \mathrm{Ra},{ }^{137} \mathrm{Cs}$ and ${ }^{40} \mathrm{~K}$, in the soil have been collected and analyzed. The soil samples were dry at $105^{\circ} \mathrm{C}$ to constant weight or dry weight (d.w.) before being analyzed in the laboratory and these were sieved through a 50-60 mesh sieve. The (dry/wet) weight ratio was recorded. The samples were analyzed for ${ }^{235} \mathrm{U},{ }^{226} \mathrm{Ra},{ }^{137} \mathrm{Cs}$ and ${ }^{40} \mathrm{~K}$ specific activities, with a HPGe detector having $29.4 \%$ of relative efficiency. Aliquots of 300-350 g were kept in a $500 \mathrm{ml}$ Marinelli beaker for a period of more than 21 days to allow radium and radon to reach the equilibrium.

Figure 1. Location of sampling points inside the SCRW (Zones I, II, III and IV) and outside at the border line to the SCRW (Zone V).

The effective gamma dose rate $\left(\mathrm{nSv} \mathrm{h} \mathrm{h}^{-1}\right)$ from terrestrial radionuclides has been calculated with the equation deduced from [2]:

$$
H_{E}=0.033 A_{40} \mathrm{~K}+0.51 A_{232} \mathrm{Th}+0.33 A_{226_{R a}}+0.001 A_{137} \mathrm{Cs}
$$

where,

$\mathrm{H}_{\mathrm{E}}$ is the effective dose in $\left(\mathrm{nSv} \mathrm{h} \mathrm{h}^{-1}\right)$ and $\mathrm{A}_{\mathrm{i}}$ is the activity concentration of the $\mathrm{i}^{\text {th }}$ radionuclide in soil samples (Bq kg $\left.{ }^{-1}\right)$ (d.w.).

\subsection{Radon exposure and dose evaluation}

From 1990 to 1992, thirteen track detection devices (SSNTD) for determining radon in gas soil and in air were distributed at fixed stations inside the SCRW (Zones I, III and Trench). Also some SSNTDs were placed at Zone V and at the regional background (Zone VI). The SSNTDs were cellulose nitrate alpha-sensitive LR 115, Type II. They were placed at $30 \mathrm{~cm}$ of depth in the soil and in plastic vessels $1 \mathrm{~m}$ from the ground. The exposure times were for 21 and 120 days respectively and they were etched and spark counted as previously reported [3]. 
To estimate the indoor radon concentration in $\left(\mathrm{Bq}^{-3}\right)$ from outdoor measurements, the mathematical model of Knutson [8] was used. The model assume a complete mixing in the indoor air and the following relationship between indoor and outdoor radon concentrations: $C_{R n}$ indoor=e' $/ v+C_{R n}$ outdoor; where: $\mathrm{C}_{\mathrm{Rn}}$ indoor and $\mathrm{C}_{\mathrm{Rn}}$ outdoor are the indoor and outdoor radon concentrations $\left(\mathrm{Bq} \mathrm{m} \mathrm{m}^{-3}\right.$ ); $\mathrm{e}^{\prime}=$ the total volume-specific entry rate of radon in $\left(\mathrm{Bq} \mathrm{m} \mathrm{m}^{-3} \mathrm{~h}^{-1}\right)$ and $\mathrm{v}=$ the ventilation rate in $\left(\mathrm{h}^{-1}\right)$. A mean ventilation rate of $0.5 \mathrm{~h}^{-1}$ in dwellings and a radon entry rate from the soil of $10 \mathrm{~Bq} \mathrm{~m}^{-3} \mathrm{~h}^{-1}$. were considered in our calculations [8]. For the representative radon concentrations, equilibrium and occupancy factors, and the dose coefficient in terms of Equilibrium Equivalent radon Concentration (EEC), the annual effective doses are derived [2] as:

$$
\mathrm{H}_{\mathrm{E}}=\mathrm{C}_{\mathrm{Rn}} \mathrm{Eq} \mathrm{T} \mathrm{CF} \mathrm{Rn}^{-6}
$$

where,

$\mathrm{H}_{\mathrm{E}}=$ the annual effective dose by inhalation of radon $\left(\mathrm{mSv}^{-1}\right) ; \mathrm{C}_{\mathrm{Rn}}=$ the radon concentration in air $\left(\mathrm{Bq} \mathrm{m}^{-3}\right)$; $\mathrm{Eq}=$ the equilibrium factor ( 0.4 and 0.6 for the indoor and outdoor environments respectively); $\mathrm{T}=$ the occupancy factors $\left(7000 \mathrm{~h} \mathrm{y}^{-1}\right.$ and $1760 \mathrm{~h} \mathrm{y}^{-1}$ for the indoor and outdoor environments to the general public; $2000 \mathrm{~h} \mathrm{y}^{-1}$ and $6760 \mathrm{~h} \mathrm{y}^{-1}$ for the outdoor and indoor environments to workers); $\mathrm{CF}_{\mathrm{Rn}}=$ dose conversion factors for radon $\left(9 \mathrm{nSv} \mathrm{Bq}{ }^{-1} \mathrm{~h}^{-1} \mathrm{~m}^{3}\right.$ and $6 \mathrm{nSv} \mathrm{Bq} \mathrm{q}^{-1} \mathrm{~m}^{3}$ in terms of EEC and the equilibrium factors of 0.4 and 0.6 for the indoor and outdoor environments respectively).

\subsection{Dose evaluation from ingested radionuclides}

The effective dose $\left(\mathrm{H}_{\mathrm{E})}\right.$, incurred from the ingestion of a given quantity of food, containing a particular radionuclide was estimated from the following expression [9]:

$$
\begin{gathered}
\mathrm{H}_{\mathrm{E}}=\Sigma_{\mathrm{I}}\left(\mathrm{C}_{\mathrm{i}}\right) \mathrm{R}_{\mathrm{i}} \mathrm{Df}_{\text {ing }} 10^{-6} \\
\mathrm{C}_{\mathrm{i}}=\mathrm{C}_{\mathrm{s}} \mathrm{TF} \mathrm{W_{ \textrm {i } }}
\end{gathered}
$$

where,

$\mathrm{H}_{\mathrm{E}=}$ the annual effective dose by ingestion in $\left(\mathrm{mSv} \mathrm{y}^{-1}\right) ; \mathrm{C}_{\mathrm{i}}=$ the activity concentration $\left(\mathrm{Bq} \mathrm{kg}^{-1}\right.$ (w.w.)) of a particular radionuclide of $i^{\text {th }}$ foodstuff; $\mathrm{C}_{\mathrm{s}}=$ the activity concentration of a particular radionuclide in soil $\left(\mathrm{Bq} \mathrm{kg}^{-1}\right.$ (d.w.)); $\mathrm{TF}=$ the soil to vegetation or soil to animal food transfer factor expressed as the concentration of an isotope in foodstuff $\left(\mathrm{Bq} \mathrm{kg}^{-1}\right.$ (d.w.)) divided by the concentration of the isotope in soil ( $\mathrm{Bq} \mathrm{kg}{ }^{-1}$ (d.w.)); $\mathrm{W}_{\mathrm{i}}=$ the (dry/wet) weight ratio of the $\mathrm{i}^{\text {th }}$ foodstuff; $\mathrm{R}_{\mathrm{i}}=$ the annual average consumption rate of $\mathrm{i}^{\text {th }}$ foodstuff $\left(\mathrm{kg} \mathrm{y}^{-1}\right.$ (w.w.)); $\mathrm{Df}_{\text {ing }}=$ the dose factor for ingestion ( $\mathrm{Sv}$ per $\left.\mathrm{Bq}\right)$ that would result from an intake of $1 \mathrm{~Bq}$ of this radionuclide. The corresponding dose factors ( $\mathrm{Sv}$ per $\mathrm{Bq}$ ) are: ${ }^{226} \mathrm{Ra}\left(2.8 \times 10^{-7}\right),{ }^{210} \mathrm{~Pb}\left(6.9 \times 10^{-7}\right),{ }^{137} \mathrm{Cs}\left(1.3 \times 10^{-8}\right)$ and ${ }^{40} \mathrm{~K}\left(6.2 \times 10^{-9}\right)$.

\section{RESULTS AND DISCUSSION}

The average activity concentrations and range values of ${ }^{226} \mathrm{Ra},{ }^{137} \mathrm{Cs}$, and ${ }^{40} \mathrm{~K}$ measured from 1991 to 2002 in soil samples at the regional background, at SCRW (zones (I+II), III and IV) and at Zone V, are shown in Table I. The outdoor gamma dose rates from terrestrial gamma exposure $\left(\mathrm{nSv} \mathrm{h}^{-1}\right)$ estimated with equation (1) are also indicated. 
Table 1. Activity concentrations in soil at the regional background (Zone VI), at SCRW (Zones I to IV) and at Zone V; external gamma effective dose estimated to the general public and workers.

\begin{tabular}{|c|c|c|c|c|c|c|c|c|c|}
\hline \multirow{3}{*}{ Year } & \multirow{3}{*}{$\mathrm{N}$} & \multicolumn{6}{|c|}{ Activity concentrations in soil (average \pm error) in $\mathrm{Bq} \mathrm{kg}^{-1}$ (d.w.) } & \multirow{3}{*}{$\begin{array}{l}\text { Dose } \\
\text { rate } \\
n S v h^{-1}\end{array}$} & \multirow{3}{*}{$\begin{array}{c}\text { Effective } \\
\text { dose } \\
\mathrm{mSv} \mathrm{y}^{-1}\end{array}$} \\
\hline & & \multicolumn{2}{|c|}{${ }^{226} \mathrm{Ra}$} & \multicolumn{2}{|c|}{${ }^{137} \mathrm{Cs}$} & \multicolumn{2}{|c|}{${ }^{40} \mathrm{~K}$} & & \\
\hline & & Average & Range & Average & Range & Average & Range & & \\
\hline \multicolumn{10}{|c|}{ Regional background (general public) } \\
\hline 1991-1995 & 10 & $24.8 \pm 4$ & $17-32$ & $4.7 \pm 0.5$ & $1.8-8$ & $288 \pm 15$ & $252-347$ & 28.91 & 0.051 \\
\hline 1996-2002 & 48 & $27.4 \pm 10$ & $12-57$ & $2.8 \pm 0.6$ & $1-10$ & $305 \pm 30$ & $187-435$ & 30.33 & 0.053 \\
\hline \multicolumn{10}{|c|}{ SCRW (Zone I+II) (workers) } \\
\hline 1991-1995 & 36 & $3738 \pm 230$ & 182-19979 & $\begin{array}{c}3273 \pm 17 \\
9 \\
\end{array}$ & $13-18148$ & $286 \pm 55$ & $198-560$ & 1260 & 2.52 \\
\hline 1996-2002 & 147 & $1019 \pm 109$ & $91-7871$ & $152 \pm 40$ & $9-1952$ & $286 \pm 37$ & $165-449$ & 360 & 0.72 \\
\hline \multicolumn{10}{|c|}{ SCRW (Zone III) (workers) } \\
\hline $1991-1995$ & 11 & $122 \pm 17$ & $36-218$ & $97 \pm 6$ & $40-158$ & $224 \pm 18$ & $204-258$ & 61.52 & 0.12 \\
\hline 1996-2002 & 37 & $53 \pm 14$ & $20-115$ & $51 \pm 7$ & $6-188$ & $244 \pm 27$ & $156-299$ & 39.36 & 0.08 \\
\hline \multicolumn{10}{|c|}{ SCRW (Zone IV) (workers) } \\
\hline 1991-1995 & 7 & $109 \pm 15$ & $21-258$ & $86 \pm 1$ & $14-136$ & $252 \pm 25$ & 204-371 & 58.14 & 0.12 \\
\hline 1996-2002 & 91 & $32 \pm 10$ & $12-66$ & $22 \pm 3$ & $2-126$ & $235 \pm 24$ & $153-331$ & 32.11 & 0.06 \\
\hline \multicolumn{10}{|c|}{ Zone V (general public) } \\
\hline 1991-1995 & 10 & $108.7 \pm 10$ & $38-237$ & $69.7 \pm 3.7$ & $16-160$ & $251 \pm 16$ & $179-276$ & 55.44 & 0.098 \\
\hline $1996-2002$ & 45 & $119.8 \pm 23$ & $36-182$ & $83.9 \pm 6.6$ & $2-148$ & $241 \pm 26$ & $198-302$ & 58.79 & 0.103 \\
\hline
\end{tabular}

The effective doses $\left(\mathrm{mSv} \mathrm{y}^{-1}\right)$ were estimated considering an occupancy factor of $1760 \mathrm{~h} \mathrm{y}^{-1}$ and $2000 \mathrm{~h} \mathrm{y}^{-1}$ to the general public and to workers respectively. At the regional background, the ${ }^{226} \mathrm{Ra}$ average value from 1991 to 2002 was $26 \mathrm{~Bq} \mathrm{~kg}^{-1}$ (d.w.). ${ }^{232} \mathrm{Th}$ appears to be essentially in secular equilibrium with its entire decay chain and gamma radiation from ${ }^{228} \mathrm{Ac},{ }^{212} \mathrm{~Pb}$ and ${ }^{208} \mathrm{Tl}$ may all be used in its determination [10]. The average values from those radionuclides, measured during 1991 were: $22 \pm 3,21 \pm 2$, and $9 \pm 1 \mathrm{~Bq} \mathrm{~kg}^{-1}$ (d.w.) for ${ }^{228} \mathrm{Ac},{ }^{212} \mathrm{~Pb}$ and ${ }^{208} \mathrm{Tl}$, respectively. $\mathrm{An}^{232} \mathrm{Th}$ average value of $22 \mathrm{~Bq} \mathrm{~kg}^{-1}$ (d.w.), was considered to estimate the gamma dose rate in air by equation (1). The concentration of ${ }^{210} \mathrm{~Pb}$ in surface soil may be 1.2 to 10 times greater than ${ }^{226} \mathrm{Ra}[11]$. An average value of $35 \mathrm{~Bq} \mathrm{~kg}{ }^{-1}$ (d.w.) to ${ }^{214} \mathrm{~Pb}$ (1.3 times greater than for ${ }^{226} \mathrm{Ra}$ ) was measured at the regional background in 1991, in agreement [11]. An ${ }^{210} \mathrm{~Pb}\left(\approx^{214} \mathrm{~Pb}\right)$ average value of $35 \mathrm{~Bq} \mathrm{~kg}^{-1}$ (d.w.) in soil was considered to estimate the effective dose by ingestion (4). Activity concentrations of ${ }^{137} \mathrm{Cs}$ and ${ }^{40} \mathrm{~K}$ average values were 4 and $297 \mathrm{~Bq} \mathrm{~kg}^{-1}$ (d.w.) respectively.

The average effective dose to the general public estimated from 1991 to 2002 was $0.052 \mathrm{mSv} \mathrm{y}^{-1}$ ( $0.259 \mathrm{mSv} \mathrm{y}^{-1}$ considering 8760 hours per year). An average external effective dose of $0.60 \mathrm{mSv} \mathrm{y}^{-1}$ at the regional background was estimated from the gamma exposure measurements (1991 to 2002) using passive integrating thermoluminescent dosemeters (TLD's) of $\mathrm{CaSO}_{4}$ : Dy [12]. That measurements include the contribution from cosmic and terrestrial radiation, so the average effective dose from cosmic radiation can be estimated by subtraction of the dose due to terrestrial gamma exposure from the total annual effective dose $(0.60-0.259)=0.34 \mathrm{mSv} \mathrm{y}^{-1}$.

At SCRW, during 2000 and 2001, $400 \mathrm{~m}^{3}$ of contaminated soil were removed from Zones (I+II). From these actions, the average values of ${ }^{226} \mathrm{Ra}$ diminished from $3738 \pm 230$ to $1019 \pm 109 \mathrm{~Bq} \mathrm{~kg}^{-1}$ (d.w.); the average values of ${ }^{235} \mathrm{U}$ were $70 \pm 8 \mathrm{~Bq} \mathrm{~kg}^{-1}$ (d.w.) range (15-168) in (1991-1995) and $24 \pm 6 \mathrm{~Bq} \mathrm{~kg}^{-1}$ (d.w.) range (6-65) in (1996-2002) periods. The ${ }^{235} \mathrm{U}^{226} \mathrm{Ra}$ isotopic ratio ranged between $0.012(1.2 \%)$ and $0.043(4.3 \%)$. At Zone II, the lowest isotopic ratio value $(1.2 \%)$ was similar to ${ }^{235} \mathrm{U} /{ }^{228} \mathrm{U}$ isotopic ratio $(1.29 \%)$ reported by Magnoni et al. [13] for the typical value for depleted uranium. However, the 
average values of ${ }^{228} \mathrm{Ac},{ }^{212} \mathrm{~Pb}$ and ${ }^{208} \mathrm{Tl}$ were: $27 \pm 5,19 \pm 2$ and $11 \pm 1 \mathrm{~Bq} \mathrm{~kg}^{-1}$ (d.w.) respectively, similar to the regional background measurements. the average effective dose to workers diminished substantially (from 2.52 to $0.72 \mathrm{mSv} \mathrm{y}^{-1}$ ) from (1991-1995) to (1996-2002) periods.

Derived intervention level adopted by the National Regulatory Commission (CNSNS) for ${ }^{226} \mathrm{Ra}$ at the SCRW is $130 \mathrm{~Bq} \mathrm{~kg}^{-1}$. At Zone $\mathrm{V}$, the maximum value $\left(237 \mathrm{~Bq} \mathrm{~kg}^{-1}\right)$ obtained in the period 1991-1995, was higher than the limits adopted internationally to exempt solid materials or as screening level for the unrestricted use (185 and $200 \mathrm{~Bq} \mathrm{~kg}^{-1}$ respectively). The activity concentrations of ${ }^{137} \mathrm{Cs}$ in the surface soil were 19 times higher than for the regional background, while average values of $246 \pm 22 \mathrm{~Bq} \mathrm{~kg}^{-1}$ (d.w.) range (179-302) and $57 \pm 12 \mathrm{~Bq} \mathrm{~kg}^{-1}$ (d.w.) range (26-85) were obtained for ${ }^{40} \mathrm{~K}$ and ${ }^{214} \mathrm{~Pb}$ respectively. Once the average value (1991-2002) of the regional background $\left(0.052 \mathrm{mSv} \mathrm{y}^{-1}\right)$ is subtracted $\left(0.101-0.052=0.048 \mathrm{mSv} \mathrm{y}^{-1}\right)$, the additional external dose is obtained for the general public $\left(1760 \mathrm{~h} \mathrm{y}^{-1}\right.$ outdoors). The external effective dose for a person living in the future at Zone $\mathrm{V}$, considering 8760 hours per year and the cosmic radiation $\left(0.34 \mathrm{mSv} \mathrm{y}^{-1}\right)$ will be $0.84 \mathrm{mSv} \mathrm{y}^{-1}$, one and a half times higher than for the regional background.

Measurements in the soil (30 cm depth) and (1m above ground) had shown the presence of enhanced concentrations of up to $1705(660-2596) \mathrm{Bq} \mathrm{m}^{-3}$ of ${ }^{222} \mathrm{Rn}$ in gas soil at Zone I and of $4747 \mathrm{~Bq} \mathrm{~m}^{-3}$ of ${ }^{222} \mathrm{Rn}$ in gas soil at the trench zone (Table 2). The average concentration values of ${ }^{222} \mathrm{Rn}$ in air at the same zones were 57 and $36 \mathrm{~Bq} \mathrm{~m}^{-3}$ respectively, while the average values of ${ }^{222} \mathrm{Rn}$ in soil and in air at the regional background were $31 \mathrm{~Bq} \mathrm{~m}^{-3}$ and $7 \mathrm{~Bq} \mathrm{~m}^{-3}$ respectively.

Table 2. ${ }^{222} \mathrm{Rn}$ concentrations (average \pm error) in $\mathrm{Bq} \mathrm{m}^{-3}$; internal effective dose to the general public and workers during 1990 to 1992.

\begin{tabular}{|c|c|c|c|c|c|c|c|}
\hline \multirow{2}{*}{\multicolumn{2}{|c|}{ Zone }} & \multirow[t]{2}{*}{$\mathrm{N}$} & \multicolumn{2}{|c|}{${ }^{222} \mathrm{Rn}$ concentration } & \multirow{2}{*}{$\begin{array}{c}\text { Effective } \\
\text { dose } \\
\text { (workers) } \\
\mathrm{mSv} \mathrm{y}^{-1}\end{array}$} & \multicolumn{2}{|c|}{$\begin{array}{c}\text { Effective dose } \\
\text { (general public) } \\
\mathrm{mSv} \mathrm{y}^{-1}\end{array}$} \\
\hline & & & $30 \mathrm{~cm}$ depth & $\begin{array}{l}1 \mathrm{~m} \text { above } \\
\text { ground }\end{array}$ & & Outdoor & Indoor \\
\hline \multicolumn{2}{|c|}{ Background (VI) } & 3 & $\begin{array}{c}31 \pm 2 \\
(26-35) \\
\end{array}$ & $7 \pm 1$ & & 0.044 & 0.68 \\
\hline \multicolumn{2}{|l|}{ Zone V } & 5 & $\begin{array}{c}134 \pm 6 \\
(77-265) \\
\end{array}$ & $\begin{array}{c}20 \pm 1 \\
(8-32) \\
\end{array}$ & & $\begin{array}{c}0.13 \\
(0.05-0.20) \\
\end{array}$ & $\begin{array}{c}1.01 \\
(0.40-1.61)\end{array}$ \\
\hline \multirow{3}{*}{ SCRW } & I & 6 & $\begin{array}{c}1705 \pm 85 \\
(660-2596) \\
\end{array}$ & $\begin{array}{c}57 \pm 2 \\
(41-78) \\
\end{array}$ & $\begin{array}{c}0.41 \\
(0.29-0.56) \\
\end{array}$ & & \\
\hline & III & 5 & $\begin{array}{l}275 \pm 11 \\
(41-753) \\
\end{array}$ & $\begin{array}{c}45 \pm 2 \\
(25-73)\end{array}$ & $\begin{array}{c}0.32 \\
(0.18-0.53) \\
\end{array}$ & & \\
\hline & Trenchs & 9 & $\begin{array}{c}805 \pm 40 \\
(44-4747)\end{array}$ & $\begin{array}{c}36 \pm 1 \\
(15-63) \\
\end{array}$ & $\begin{array}{c}0.26 \\
(0.11-0.45) \\
\end{array}$ & & \\
\hline \multicolumn{2}{|c|}{ SCRW (average) } & 20 & $928 \pm 46$ & $48 \pm 2$ & 0.33 & & \\
\hline
\end{tabular}

The average indoor radon concentration values estimated at regional background (Zone VI) and at Zone $\mathrm{V}$ are:

$$
\begin{aligned}
& \mathrm{C}_{\mathrm{Rn}} \text { indoor }_{(\text {Zone VI) }}=10\left(\mathrm{~Bq} \mathrm{~m}^{-3} \mathrm{~h}^{-1}\right) / 0.5\left(\mathrm{~h}^{-1}\right)+7\left(\mathrm{~Bq} \mathrm{~m}^{-3}\right)=27\left(\mathrm{~Bq} \mathrm{~m}^{-3}\right) \\
& \mathrm{C}_{\mathrm{Rn}} \text { indoor }_{\text {(Zone } \mathrm{V})}=10\left(\mathrm{~Bq} \mathrm{~m}^{-3} \mathrm{~h}^{-1}\right) / 0.5\left(\mathrm{~h}^{-1}\right)+20\left(\mathrm{~Bq} \mathrm{~m}^{-3}\right)=40\left(\mathrm{~Bq} \mathrm{~m}^{-3}\right)
\end{aligned}
$$

In Mexico City, relatively near of the SCRW, the average radon concentration values from 50 dwellings [14], showed an average indoor radon concentration of $19.2 \mathrm{~Bq} \mathrm{~m}^{-3}$ (range 4-115) and outdoors: $13 \mathrm{~Bq} \mathrm{~m}^{-3}$ (range 4-57). The city of Zacatecas, with a climate cooler than Mexico City, shows an average indoor radon value of 46.2 (14-86) $\mathrm{Bq} \mathrm{m}^{-3}$ and 23.1 (4-56) $\mathrm{Bq} \mathrm{m}^{-3}$ outdoors [14]. 
For the representative background radon concentrations, equilibrium and occupancy factors, and the dose coefficient, the following annual effective doses are derived from the regional background: Indoors: $27 \mathrm{~Bq} \mathrm{~m}^{-3} \times 0.4 \times 9 \mathrm{nSv} \mathrm{Bq}^{-1} \mathrm{~h}^{-1} \mathrm{~m}^{3} \times 7000 \mathrm{~h} \mathrm{y}^{-1} \times 10^{-6} \mathrm{mSv} \mathrm{nSv}^{-1}=0.68 \mathrm{mSv} \mathrm{y}^{-1}$ and Outdoors: $7 \mathrm{~Bq} \mathrm{~m}{ }^{-3} \times 0.6 \times 6 \mathrm{nSv} \mathrm{Bq}^{-1} \mathrm{~h}^{-1} \mathrm{~m}^{3} \times 1760 \mathrm{~h} \mathrm{y}^{-1} \times 10^{-6} \mathrm{mSv} \mathrm{nSv}^{-1}=0.044 \mathrm{mSv} \mathrm{y}^{-1}$

If we add the minor contribution from radon dissolved in blood (0.06) and from thoron and their short-lived decay products $(0.1)$ [2], at the total value obtained $\left(0.724 \mathrm{mSv} \mathrm{y}^{-1}\right)$, the average exposure to radon at the regional background (Zone VI) would be: $0.884 \mathrm{mSv}^{-1}$.

The world average concentration values for ${ }^{222} \mathrm{Rn}$ are: $40(2-50) \mathrm{Bq} \mathrm{m}^{-3}$ indoor and 3-7 $\mathrm{Bq} \mathrm{m}^{-3}$ outdoor and for ${ }^{220} \mathrm{Rn}: 0.3 \mathrm{~Bq} \mathrm{~m}^{-3}$ indoor and $0.1 \mathrm{~Bq} \mathrm{~m}^{-3}$ outdoor. The corresponding average doses from ${ }^{222} \mathrm{Rn}$ are: $0.67 \mathrm{mSv} \mathrm{y}^{-1}$ and $0.02 \mathrm{mSv} \mathrm{y}^{-1}$ for the indoor and outdoor environments respectively; the contribution by thoron and its decay products is about $0.1 \mathrm{mSv}$ [2].

Monitoring of conventional agricultural and wild animal products for the local market (Zone VI) and of some wild products at SCRW and at Zone V are undertaken to determine levels of activity and doses estimations to the consuming populace. The food group and consumption rates included in the routine surveillance programme are shown in Table 3. For dose estimations, the average values of radioactivity in the soil (1991-2002) at Zone VI were considered while at Zone V, the average values from (1996-2002) were taken.

Table 3. Average consumption rate, (dry/wet) weight ratios and transfer factors soil-local foods; effective dose by ingestion estimated in wet weight for the general public at background (Zone VI) and at Zone V.

\begin{tabular}{|c|c|c|c|c|c|c|c|c|}
\hline \multirow[t]{2}{*}{ Food group } & \multirow{2}{*}{$\begin{array}{c}\text { Consumption } \\
\text { rate } \\
\mathrm{kg} \mathrm{y}^{-1} \text { (w.w) } \\
\end{array}$} & \multirow{2}{*}{$\begin{array}{c}\text { dry/wet } \\
\text { weight } \\
\text { ratio }\end{array}$} & \multicolumn{4}{|c|}{ Transfer factor (TF) (d.w.) } & \multicolumn{2}{|c|}{$\begin{array}{l}\text { Effective dose } \\
\quad\left(\mathrm{mSv} \mathrm{y}^{-1}\right)\end{array}$} \\
\hline & & & ${ }^{226} \mathrm{Ra}$ & ${ }^{210} \mathrm{~Pb}$ & ${ }^{137} \mathrm{Cs}$ & ${ }^{40} \mathrm{~K}$ & Zone VI & Zone V \\
\hline Helix aspersa & 10 & 0.2 & 0.69 & 0.90 & 0.25 & 0.57 & 0.056 & 0.119 \\
\hline $\begin{array}{l}\text { Lyometopum } \\
\text { appiculatum }\end{array}$ & 5 & 0.3 & 0.30 & 0.30 & 0.10 & 0.67 & 0.016 & 0.035 \\
\hline Opuntia megacantha & 25 & 0.2 & 0.30 & 0.09 & 0.30 & 3 & 0.049 & 0.092 \\
\hline Agave atrovirens & 15 & 0.4 & 0.80 & 0.09 & 0.30 & 2 & 0.070 & 0.202 \\
\hline Avena sativa & 10 & 0.3 & 0.04 & 0.02 & 0.03 & 0.90 & 0.0073 & 0.011 \\
\hline Zea mays & 40 & 0.8 & 0.04 & 0.02 & 0.001 & 0.90 & 0.078 & 0.111 \\
\hline Phaseolus vulgaris & 40 & 0.8 & 0.04 & 0.02 & 0.01 & 0.90 & 0.078 & 0.112 \\
\hline Other vegetables & 70 & 0.2 & 0.20 & 0.09 & 0.20 & 3 & 0.128 & 0.209 \\
\hline $\begin{array}{c}\text { Effective dose }\left(\mathrm{mSv} \mathrm{y}^{-1}\right) \\
\text { Zone VI }(\mathrm{ZoneV}) \\
\end{array}$ & 215 & & $0.10(0.46$ & $14(0.23)$ & $\begin{array}{l}0.0004 \\
(0.008)\end{array}$ & $\begin{array}{c}0.24 \\
(0.19)\end{array}$ & 0.482 & 0.891 \\
\hline
\end{tabular}

The local wild foods sampled were: land snails (Helix aspersa), "escamoles" known as eggs (immature stages of the ant specie Lyometopum appiculatum,), "nopal" (Opuntia megacantha), "maguey" (Agave atrovirens) and oat (Avena sativa), corn (Zea mays Sacharata) and beans (Phaseolus vulgaris Jamapa), that were cultivated "in situ" reproducing the local agricultural practices [7]. For other vegetables not locally produced and which do not have radiation measurements, we take the TF from [9]. If the average value of the dose by ingestion estimated for regional background $\left(0.482 \mathrm{mSv} \mathrm{y}^{-1}\right)$ is subtracted $\left(0.891-0.482=0.409 \mathrm{mSv} \mathrm{y}^{-1}\right)$, the additional dose by ingestion is obtained for the general public at Zone V. At Zone VI the main contributions (50\%) of the total ingestion correspond to ${ }^{40} \mathrm{~K}$, followed by ${ }^{210} \mathrm{~Pb}(29 \%)$ and ${ }^{226} \mathrm{Ra}(21 \%)$. At Zone $\mathrm{V}$, the estimated supplementary dose via ingestion was $0.41 \mathrm{mSv} \mathrm{y}^{-1}$.

\section{CONCLUSIONS}

As a result of the activity deposited on soil at SCRW, we found at Zone V, in the upper $10 \mathrm{~cm}$ layer of soils, four times higher concentrations of ${ }^{226} \mathrm{Ra}$ and 19 times higher concentrations of ${ }^{137} \mathrm{Cs}$ than for the regional background (considering the average values). The excess in specific activities results in an increase in exposure to gamma rays. The supplementary average effective dose defined as the addition of all the possible pathways (external, inhalation and ingestion) for a person living at Zone $\mathrm{V}$ 
will be $0.87 \mathrm{mSv} \mathrm{y}^{-1}$. If the calculation is made considering $8760 \mathrm{~h} \mathrm{y}^{-1}$, the average annual effective dose (external, inhalation and ingestion) for the population at Zone VI (background) is $1.97 \mathrm{mSv} \mathrm{y}^{-1}$ and $3.03 \mathrm{mSv} \mathrm{y}^{-1}$ at Zone $\mathrm{V}\left(1.1 \mathrm{mSv} \mathrm{y}^{-1}\right.$ additional). At SCRW (Zones I+II) the average external effective dose (1991-2002) from terrestrial gamma field was estimated to be: $1.62 \mathrm{mSv} \mathrm{h}^{-1}, 31$ times higher than for the regional background $\left(0.052 \mathrm{mSv} \mathrm{h}^{-1}\right)$. For workers the additional average dose (external and radon outdoors) was $1.9 \mathrm{mSv} \mathrm{y}^{-1}$. If the maximum values (1991-1995) are considered, the dose would reach $3 \mathrm{mSv} \mathrm{y}^{-1}$. At present time there is no population inhabiting Zone $\mathrm{V}$ and adverse health effects from increased natural background radioactivity may seem unlikely for the near term. However for a future scenario, where people would live at this zone adverse health effects for the long-term accumulation of radioactive materials from the SCRW could occur. Restriction of land use, with special emphasis on the control of ${ }^{226} \mathrm{Ra}$, or even remediation would be advisable.

\section{Acknowledgements}

The authors acknowledge E. Quintero, F. Montes, L. Cervantes, G. Valentin, R. Benitez and V. Rojas for technical assistance.

\section{References}

[1] Van der Stricht E. and Kirchmann R., Radioecology, Radioactivity \& Ecosystems (FORTEMPS, Liege, 2001).

[2] UNSCEAR, Sources and effects of ionizing radiation, Annex A and B. Report to the General Assembly of the United Nations with Scientific Annexes, United Nations publication E.00.IX.3, New York (2000).

[3] Segovia N., Gaso M.I., Chavez A., Tejera A., Gutierrez A., Azorin J., Balcazar M., Lopez A., Tamez E., Cervantes L., Monnin M., Radiat. Prot. Dosim. 34 (1990) 219-222.

[4] Gaso M.I., Segovia N., Cervantes L., Salazar S., in Environmental Radiochemical Analysis, edited by G.W.A. Newton, (The Royal Society of Chemistry, Cambridge, 1999) p. 50-57.

[5] Gaso M.I., Segovia N., Morton O., "In situ biological monitoring of radioactivity and metal pollution in terrestrial snails Helix aspersa from a semiarid ecosystem”, Radioprot. Colloques, 37 (2002b) 865-871.

[6] Gaso M.I., Segovia N., Morton O., Armienta M.A., in Environmental Radiochemical Analysis II, edited by P. Warwick, (The Royal Society of Chemistry, Cambridge, 2003) p. 334-339.

[7] Cervantes L., Segovia N., Gaso M.I., Palacios J.C. "Soil to plant transfer factors in Zea mays and Phaseolus vulgaris in a semi-arid ecosystem from a radioactive waste site", Technologically enhanced natural radiation (TENR II), IAEA TEC-DOC 1271, (Vienna, 2002) 149-157.

[8] CEE (Comisión of the European Communities), Fifth international symposium on the natural radiation environment, Report EUR 14411 EN, Luxembourg, (1993).

[9] NCRP (National Council on Radiation Protection and Measurements), Recommended screening limits for contaminated surface soil and review of factors relevant to site-specific studies, NCRP Report No. 129, Bethesda, MD 20814-3095 (1999).

[10] Harbottle G., Evans C.V., Radioac. \& Radiochem., 8 (1997) 38-46.

[11] Fisenne I.M., Perry P.M., Decker K.M., Keller H.W., Health Phys. 53 (1987) 357-363.

[12] Gaso M.I., Segovia N., Gonzalez P.R., Montes F., "Environmental gamma dose rate around a radioactive waste site in Central Mexico", $11^{\text {th }}$ International Congress of the International Radiation Protection Association (IRPA), Madrid, 2004, 23-28 May, 6c16.

[13] Magnoni M., Bertino S., Belloto B., Campi M., Radiat. Prot. Dosim., 97 (2001) 337-340.

[14] Segovia N., Tamez E., Peña P., Gaso I., Mireles F., Davila I., Quirino L., Radiat. Prot. Dosim., 56 (1994) 157-160. 